TURIZAM

Volume 20, Issue 4

168-179 (2016)

ORIGINAL

SCIENTIFIC PAPER

\title{
Calculating the Cost of Turnover at 5-Star Hotels in Turkey between 2000 and 2016
}

\author{
Akın Aksu' ${ }^{A^{*}}$, Dilara Bahtiyar ${ }^{\mathrm{B}}$, İrem Deveci ${ }^{\mathrm{B}}$, Yavuz Koç \\ Received: October 2016 | Accepted: December 2016 \\ DOI: 10.18421/TRZ20.04-01
}

\begin{abstract}
The hospitality industry inherently involves high levels of staff-customer interactions and high turnover rates, which can potentially have a negative effect on the nature of those relationships, increase costs, and lower revenues. This study collects data for seven hotel positions (housekeeper, reservation chief, food E beverage manager, front office manager, accounting clerk, kitchen staff, and technical service manager) from nineteen 5-star hotels in Turkey from 2000 to 2016. The estimated costs in 2016 of turnover for a housekeeper was between 2,179 US\$ and 5,475 US\$, between 2,009 US\$ and 7,221 US\$ for a reservation chief, between 8,283 US\$ and 29,996 US\$ for a food \& beverage manager, and between 11,555 US\$ and 24,391 US\$ for a front office manager. The paper also discusses the implications of these findings.
\end{abstract}

Keywords: Employee turnover, costs, Tourism

\section{Introduction}

According to the UNWTO, international tourism revenues in destinations worldwide grew 3.6 $\%$ in 2015 , and the tourism sector's share of world exports increased to $7 \%$. Revenues in this sector consist of accommodation, food and beverage, entertainment, shopping, and other goods and services related to tourism (UNWTO, World Tourism Barometer, 2016:1). In 2015, international tourist arrivals reached 1.114 million people, with China (165 billion US\$), the US (112 billion US\$), Germany ( 92 billion US\$), the UK (58 billion US\$), and Russia ( 50 billion US\$) as the biggest spenders. One in 11 jobs and $30 \%$ of services exports worldwide are within the tourism sector (www2.unwto.org/content/why-tourism).

The tourism subsector of the service industry requires high levels of employee-customer interaction, highlighting the importance of turnover in this industry. Previous studies define personnel turnover as the rate at which employers add and lose personnel (Chikwe, 2009: 44) or as any permanent departure beyond organizational boundaries (Cascio, 1989). The high

Akdeniz University Faculty of Tourism Antalya, Turkey

B Akdeniz University Social Sciences Institute Antalya, Turkey, dilarabahtiyar0790@gmail.com; irem_irem05@hotmail.com; kocyavuz@gmail.com

Corresponding author: aaksu@akdeniz.edu.tr 
competition and dynamism mean that firms in the industry will continue to see personnel changes (Pearlman, Schaffer, 2013: 218).

Though turnover is an important topic, there are few studies in Turkey. This study calculates the costs of involuntary turnover at 5-star hotels operating in Antalya, Turkey. Five-star hotels were selected because, in this context, they have accurate and detailed information. Antalya is a popular destination with well-known potential. This study focuses on involuntary turnover costs since these can be especially high after an employee's first year of employment and are greater than the costs for voluntary turnover. Therefore, this study hopes to provide valuable information, especially for the Turkish context.

\section{Literature Review}

The literature defines four types of turnover: voluntary, involuntary, functional, and dysfunctional. In voluntary turnover, employees leave a firm at their own discretion, while in involuntary turnover, a firm ends the relationship with the employee. Researchers have been interested in turnover subject for nearly 90 years (Welles, Peachey, 2010: 26). Lee (1966) and Chalkiti and Sigala (2010) argue that the factors that explain turnover are related to migration theories. The push factors decrease satisfaction and the pull factors increase satisfaction (Chalkiti, Sigala, 2010: 336). The physical and psychological problems among employees in the tourism sector mean that managers have an increasingly difficult time recruiting qualified personnel and evaluating recruitment processes (Davidson, 2011: 236). According to hoteliers, turnover may negatively affect quality levels and decision-making mechanisms (Davidson, Wang, 2011:236, 237).

Turnover rates in the tourism sector are higher than in other sectors, mainly due to seasonality. This requires strategies that account for this reality (Jolliffe, Farnsworth, 2003: 312, 313). Besides seasonality, other issues include low salary, and performance, bad relationships with people, or a lack of or insufficient job guarantees and career planning, family-related problems. Benefiting from Lashley's (2011) study, Davidson and Wang (2011) described the possible reasons behind turnover, listed below in Table 1.

Table 1. Push and Pull Factors in Turnover

\begin{tabular}{|l|l|}
\hline Push Factors & Pull Factors \\
\hline Insufficient training & High salary \\
\hline Bad relationship with supervisors & Better working hours \\
\hline Insufficient organizational image & Continuous employment \\
\hline Insufficient terms and conditions & Alternative employment \\
\hline Irregular work conditions & Better career potential \\
\hline Low salary & Better training and individual development \\
\hline Long and irregular working hours & Empowerment \\
\hline Insufficient autonomy & \\
\hline
\end{tabular}

Source: Davidson, Wang, 2011: 238

According to an HCITB Report, turnover rates were $19 \%$ for managers, $55 \%$ for artisans, 65 $\%$ for operatives, $94 \%$ for supervisors, and $86 \%$ for hotels and guesthouses (Mullins, 1992). The US Bureau of Labor found a $52.2 \%$ voluntary turnover rate in the leisure and hospitality indus- 
try (Davidson, et al., 2010: 453). Referring to Hatipoğlu et al. (2013), Emiroğlu et al. (2015) stated that even in Turkey (a developing country) İstanbul's hotels had a $21.9 \%$ turnover rate in 2013 (Emiroğlu et al., 2015: 386).With 2014 figure, total turnover rate was founded as $27.6 \%$ in hospitality industry in Bangkok (Tongchaiprasit, Ariyabuddhiphongs, 2016: 34).

Turnover costs can be as high as 2,00o US\$ to 3,0oo US\$ for skilled line cooks and servers (Drummond, 1990). Others report direct costs of 2,090 US\$ for non-managerial positions (Pollin, Brenner, 200o). Personnel cost is also a primary concern for restaurant managers, operators, and other restaurant positions (Mathe, 2012:401; Walzack, Reuter, 2004). The National Restaurant Association cites turnover costs of 5,00o US\$ per restaurant employee (Gustafson, 2002: 109). A study in 1990 in the US reported turnover costs per employee of between 2,9004,700 US\$ and 17,000-20,00o US\$ for top management positions (Grandone, 1994: 3-6). The hidden and visible costs of turnover may be as much as 11 billion annually (Abbasi, Hollman, 2000; Wells, Peachey, 2011:26). USA can be given as an example of over 11 billion annual turnover cost for companies (Josiam, et al., 2011: 18). However, despite this earlier research and the importance of travel agencies in the tourism sector, there are few studies of turnover for travel agency personnel (Kim, 2014: 56).

\section{Methodology}

\section{Data Collection}

This study used questionnaires to survey human resources managers face-to-face in the sampled hotels, and all responses were evaluated separately. All related data to calculate the costs of involuntary turnover were collected from the human resource managers for 7 positions: 1) Housekeeper with 2 years' experience; 2) Reservation Chief with 1 year of experience; 3) Food \& Beverage Manager with 3 years' experience; 4) Front Office Manager with 5 years' experience; 5) Accounting Clerk with 1 year of experience; 6) kitchen staff with 3 years' experience and 7) Technical Services Manager with 4 years' experience. These seven positions were selected as examples. For confidentiality, each hotel is represented using a letter assignment. The samples were taken from six hotels in 2000, seven hotels in 2010, and six in 2016.

\section{Calculations}

While it is nearly impossible to calculate the complete costs of turnover in reality, earlier studies have used soft calculation approaches. In most cases, it is possible to calculate the direct costs, though calculating indirect costs such as loss of productivity, skill development, and loss of image are much more difficult. This study calculated involuntary turnover for 5-star hotels in the sample using Cascio's $(1995: 582,583)$ three components of separation costs, replacement costs, and training costs. Table 2 summarizes each component. 
Table 2. Personnel Turnover Cost Components

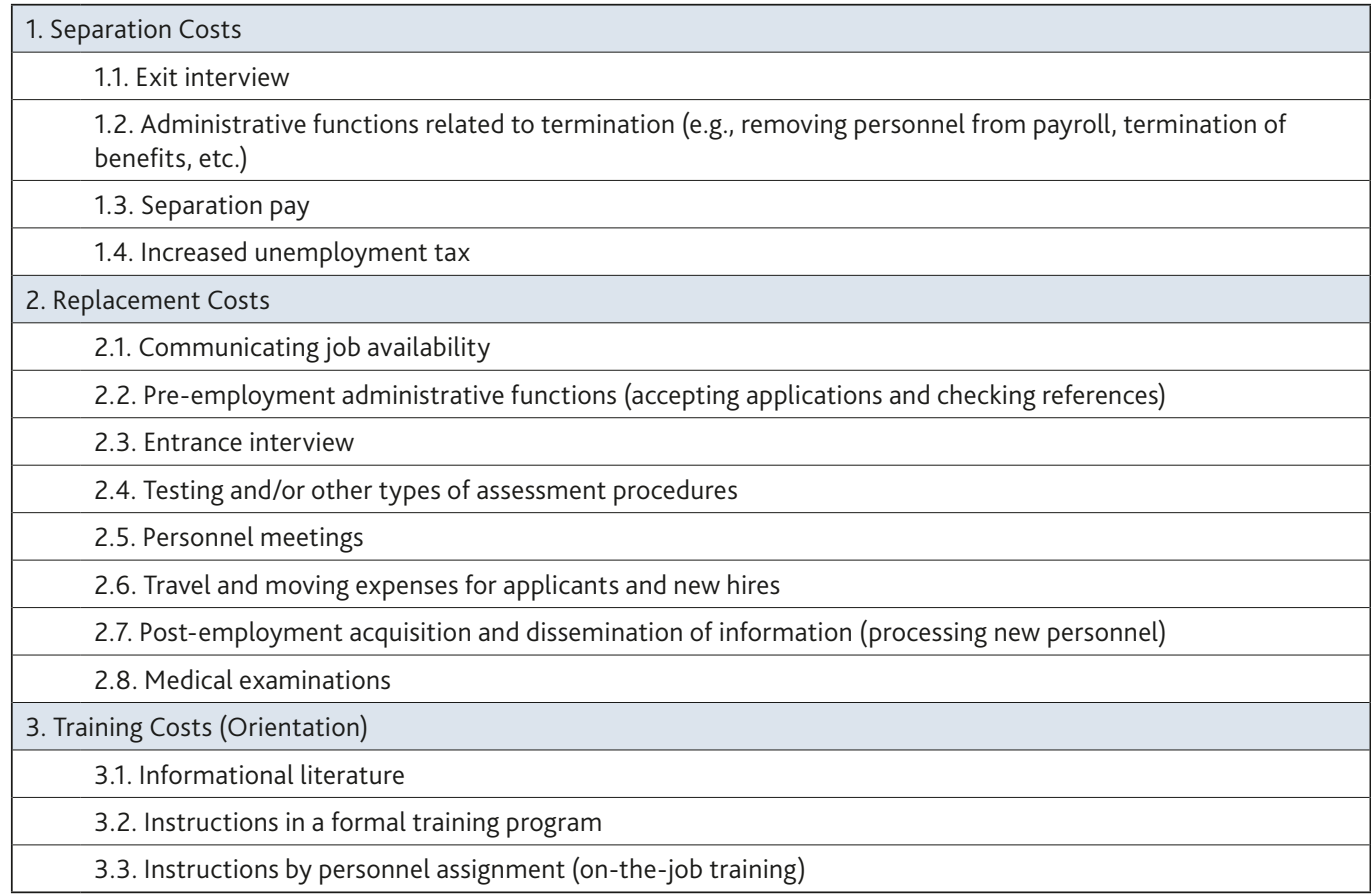

Source: Cascio (1995: 582, 583)

\section{Separation Costs}

Exit interview

$\mathrm{CIT}=(\mathrm{TRPI}+\mathrm{TRI}) \mathrm{X}$ IPR

CIT: Cost of interviewer's time

TRPI: Time required of interviewer prior to interview

TRI: Time required for interview

IPR: Interviewer's pay rate

CTTE $=$ TRTEI X PRE

CTTE: Cost of time for terminated employee

TRTEI: Time required for terminated employee's interview

PRE: Pay rate of employee

1.2. Administrative functions

$\mathrm{CAF}=\mathrm{TRAF} \mathrm{X}$ PRRP

CAF: Cost of administrative functions

TRAF: Time required for administrative functions

PRRP: Pay rate of responsible person 


\subsection{Separation pay}

This measure was changed from the original to account for Turkey's regulations, which require two legal separation payments: severance pay and leave compensation. For severance pay, employees must have worked a minimum of 1 year, and the maximum amount paid in 2000, 2010 and 2016 could not exceed the maximum payment, which the Turkish government sets twice per year. For example, the maximum payment was $841 \mathrm{US} \$$ in 2000 . Hotels can pay leave compensation either by paying the terminated employee according to his/her work experience or providing leave to the terminated employee according to his/her work experience. Legally, employees are entitled to 14, 28, 42, and 56 days off for work experience less than 6 months, 6 months to 1.5 years, 1.5 to 3 years, and 3 years or more, respectively. All hotels in the sample stated a preference for paying terminated employees.

1.4. Increased unemployment tax.

\section{Replacement Costs}

2.1. Communicating job availability

This cost varies according to the communication method.

2.2. Pre-employment administrative functions

PEAF $=$ TRPEA $X$ PRRP

PEAF: Pre-employment administrative functions

TRPEA: Time required for pre-employment administrative functions

PRRP: Pay rate of responsible person

2.3. Entrance interview

$E I=(T R I P I+T R I) X I P R$

EI: Entrance interview

TRIPI: Time required of interviewer prior to interview

TRI: Time required for interview

IPR: Interviwer's pay rate

2.4. Testing and/or other types of assessment procedures

This varies by testing method.

2.5. Employee meetings

$\mathrm{EM}=\mathrm{TRREM} \mathrm{X}$ PRRE

EM: Employee meetings 
TRREM: Time required of responsible employee for meeting

PRRE: Pay rate of responsible employee

2.6. Travel and moving expenses

This varies according to the travel options.

2.7. Post-employment acquisition and dissemination of information

PEADI $=$ TRP $X$ PRRE

PEADI: Post-employment acquisition and dissemination of information

TRP: Time required for the process

PRRE: Pay rate of responsible employee

2.8. Medical examinations

A firm pays for the total cost of medical examinations for new employees.

3. Training Costs

The total training costs for new employees include both internal and external training.

To calculate the turnover costs, the gross monthly wages of employees are divided by 30 to determine the daily figures, which are then converted to hourly wages. The formulas can thus use hourly wages for the calculations. The daily amounts were then divided by 450 ( 7.5 hours $x$ 60 minutes) to find wages per minute. The average working hours for the sample were assumed to be 7.5 per day, though in the hospitality industry, there are many cases when this is higher. The calculations were conducted for 2000,2010 and 2016 using the same research method, assumptions, and cost components for the seven positions. All calculations were first made in Turkish Lira and then converted to US dollars according to the currency rates of the Turkish Central Bank for comparability to other studies and international contexts.

\section{Results}

Table 3 reports the total involuntary turnover costs for 2016, while the figures for 2000 and 2010 appear in Tables 4 and 5, respectively (See Appendix). The results show that with increases in qualification and experience, the costs of turnover increase. For 2016, the turnover costs for a housekeeper are between 2,179 US\$ and 5,475 US\$, between 2,009 US\$ and 7,221 US\$ for a reservation chief, between 8,283 US $\$$ and 29,996 US\$ for a food \& beverage manager, and between 11,555 US\$ and 24,391 US\$ for a front office manager. For 2000, 2010 and 2016, the cost of involuntary turnover for a housekeeper, the only common position in all three years, increased from a minimum of 721 US\$ in 2000 to a maximum of 5,475 US\$ in 2016.

The turnover costs for the hotels in the sample varied due to their differing wage and human resource policies and procedures. This result is of primary interest to human resource managers. Since the minimum wage is common in Turkey, the total costs of turnover should be simi- 
lar as in other sectors. However, the costs will be different for firms paying more than the minimum wage. Within the sample, few hotels train their employees, so these costs are very low. In addition, none of the hotels in the sample in 2016 provided employee orientation.

\section{Conclusions}

This study examined the cost of involuntary personnel turnover, which in Turkey's legal environment, is much higher than voluntary turnover because the cost includes severance pay and leave compensation. Without these two additional components, the costs would actually be the same. Overall, the sample shows that there was no difference among the hotels in terms of looking for staff, wages, and importance of personnel. However, hotels must be careful, especially regarding involuntary turnover, because this generally serves as a red flag to employees and potential applicants. Hotels with consistently high involuntary turnover rates could have serious problems recruiting new employees in the future.

Trade unions and employment laws will naturally have a significant effect on turnover. However, in the current economic environment in Turkey people are "happy" because they have a job, and tend to disregard aspects such as suitability, working conditions, working atmosphere, whether the firm has career planning, and so on.

The minimum wage is the most common in all sectors, though there are also free market supply and demand factors that define wages. Aside from wages, employers in Turkey add value through other benefits such as holiday allowances. 14 days off for work experience of less than 5 years and 21 days off for the work experience of 5 years and more. This benefit thus appears in the turnover calculations.

This study does have several limitations. First, the sample includes only a limited number of 5 -star hotels at three different times. Other studies exist with wider samples and in different regions of Turkey. Additionally, there are ranges in turnover costs due to differences in wages and human resource policies at each hotel. The more research to be done will give better results in future. Second, the calculations were based on replies from human resource managers, with no other verification. Third, this study calculated all cost components using a "soft calculation" approach to account for the difficulty in calculating indirect costs. Finally, differences by gender or other demographic factor were out of the scope of this study.

This study focused mainly on calculations of involuntary turnover costs. Future research can extend this study and address the limitations by addressing short and long term prescriptions, calculating monthly and yearly rates, demographic differences, reasons for leaving or termination, and departmental distributions. In the international context, this study is among the few to address the cost of turnover in Turkey. Though it adapts existing calculation methods to Turkey's regulatory environment for only seven positions at nineteen 5-star hotels, the results are useful for hotel managers and researchers interested in the financial aspects of employee turnover. 


\section{References}

Abbasi, S.M., Hollman, K.W. 20oo. Turnover: The Real Bottom Line. Public Personnel Management 29, 333-342.

Cascio, W.F. 1989. Managing Human Resources Productivity, Quality of Worklife Profits. Mc Graw-Hill, Inc $2^{\text {nd }}$ ed. Denver.

Cascio, W.F. 1995. Managing Human Resources Productivity, Quality of Worklife Profits. Mc Graw-Hill, Inc 4th ed. New York.

Chalkiti, K., Sigala, M. 2010. Staff Turnover in the Greek Tourism Industry. International Journal of Contemporary Hospitality Management 22, 3, 335-359.

Chikwe, A.C. 2009. The Impact of Employee Turnover: The Case of Leisure, Tourism and Hospitality Industry. The Consortium Journal 14, 1, 43-56.

Davidson, M.C.G, Timo, N., Wang, Y. 2010. How Much Does Labour Turnover Cost?: A Case Study of Australian Four and Five Star Hotels. International Journal of Contemporary Hospitality Management 22, 4, 451-466.

Davidson, M.C.G, Wang, Y. 2011. Sustainable Labor Practices? Hotel Human Resource Managers Views on Turnover and Skill Shortages. Journal of Human Resources in Hospitality $\mathcal{E}$ Tourism 10, 235-253.

Drummond, K.E. 1990. Human Resource Management For The Hospitality Industry. Van Nostrand Reinhold, New York.

Emiroğlu, B.D. Akova, O., Tanrıverdi, H. 2015. The Relationship Between Turnover Intention and Demographic Factors in Hotel Business: A Study At Five Star Hotels in İstanbul. Procedia Social and Behavioral Sciences 207, 385-397.

Grandone, V. 1994. Tourism and Employment Policy Initiatives in Tourism Labour Markets. OECD Seminar.

Gustafson, C.M. 2002. Employee Turnover: A Study of Private Clubs in the USA. International Journal of Contemporary Hospitality Management 14, 3, 106-113.

Hatipoğlu, B., Alvarez, M.D., Inelmen, K., Unalan, D. 2013. İstanbul Otellerinin 3600 Değerlendirmesi Araştırma Proje Raporu. TUROB 1-95.

Jolliffe, L., Farnsworth, R. 2003. Seasonality in Tourism Employment: Human Resource Challenges. International Journal of Contemporary Hospitality Management 15, 6, 312-316.

Josiam, B.M, Clay, J. M., Graff, S. 2011. Who Will Stay and Who Will Go: Predicting Club General Manager Turnover. TOURISMOS: An International Multidisciplinary Journal of Tourism 6, 2, 17-31.

Kim, N. 2014. Employee Turnover Intention Among Newcomers in Travel Industry. International Journal of Tourism Research 16, 56-64.

Lee, E. 1966. A Theory of Migration. Demography 3, 47-57.

Lashley, C. 20oo. Hospitality Retail Management: A Unit Manager's Handbook. Butterworth-Heinemann, Oxford.

Mathe, K. 2012. Food Safety, Labor-Costs, and the Effects on Quick Service Restaurant Revenues. Journal of Food Service Business Research 15, 398-410.

Mullins, L.J. 1992. Hospitality Management A Human Resources Approach. Pitman Publishing, London.

Pearlman, D.M., Schaffer, J.D. 2013. Labor Issues Within the Hospitality and Tourism Industry: A Study of Louisianais Attempted Solutions. Journal of Human Resources in Hospitality \& Tourism 12, 217-242. 
Tongchaiprasit, P., Ariyabuddhiphongs, V. 2016. Creavity and Turnover Intention Among Hotel Chefs: The Mediating Effects of Job Satisfaction and Job Stress. International Journal of Hospitality Management 55, 33-40.

UNWTO 2016. World Tourism Barometer 14, 1-6.

Walczak, D., Reuter, M. 2004. Putting Restaurant Customers at Risk: Unsafe Food Handling as Corporate Violence. International Journal of Hospitality Management 23/1, 3-13.

Wells, J.E., Peachey, J.W. 2010. Turnover Intentions Do Leadership Behaviors and Satisfaction With the Leader Matter? Team Performance Management 17, 1/2, 23-40.

Internet: www2.unwto.org/content/why-tourism

\section{Appendix}

Table 3. Involuntary Turnover Costs For 2016

\begin{tabular}{|c|c|c|c|c|c|c|c|c|c|c|c|}
\hline & 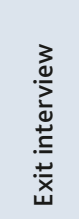 & 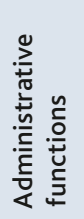 & 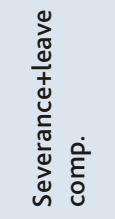 & 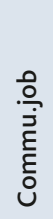 & 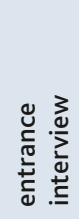 & 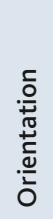 & 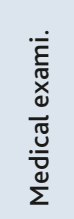 & 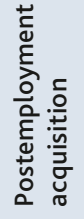 & 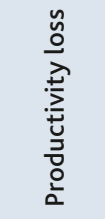 & 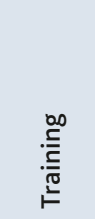 & 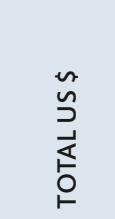 \\
\hline \multicolumn{12}{|l|}{ HOTEL "A" } \\
\hline Housekeeper & 0.88 & 3.98 & 2273.5 & - & 1.17 & - & 2.36 & 2.65 & 133.76 & 21.23 & 2439.53 \\
\hline Reservation Chief & 1.56 & 3.98 & 1928.52 & - & 2.34 & - & 2.36 & 2.65 & 1911 & 21.23 & 3873.64 \\
\hline F\&B Manager & 5.24 & 3.98 & 7166 & - & 31.42 & - & 2.36 & 2.65 & 1051 & 21.23 & 8283.88 \\
\hline $\begin{array}{l}\text { Front Office } \\
\text { Manager }\end{array}$ & 5.24 & 3.98 & 11147 & - & 31.42 & - & 2.36 & 2.65 & 1051 & 21.23 & 12264.88 \\
\hline \multicolumn{12}{|l|}{ HOTEL "B" } \\
\hline Housekeeper & 1 & 4.67 & 1861.3 & - & 1.56 & - & 0.61 & 4.67 & 286.6 & 18.68 & 2179.09 \\
\hline Reservation Chief & 3.11 & 4.67 & 1751.6 & - & 2.92 & - & 0.61 & 4.67 & 223 & 18.68 & 2009.26 \\
\hline F\&B Manager & 15.71 & 4.67 & 8598.8 & - & 15.71 & - & 0.61 & 4.67 & 490.4 & 18.68 & 9149.25 \\
\hline $\begin{array}{l}\text { Front Office } \\
\text { Manager }\end{array}$ & 15.71 & 4.67 & 11394 & - & 15.71 & - & 0.61 & 4.67 & 613 & 18.68 & 12067.05 \\
\hline \multicolumn{12}{|l|}{ HOTEL "C" } \\
\hline Housekeeper & 1.56 & 2.34 & 2442.3 & - & 0.5 & - & 1.03 & 2.34 & 223 & 2802 & 5475.07 \\
\hline Reservation Chief & 1.56 & 2.34 & 1980 & - & 2.34 & - & 1.03 & 2.34 & 318.5 & 2802 & 5110.11 \\
\hline F\&B Manager & 1.56 & 2.34 & 6681.2 & - & 2.34 & & 1.03 & 2.34 & 494 & 2802 & 9986.81 \\
\hline $\begin{array}{l}\text { Front Office } \\
\text { Manager }\end{array}$ & 1.56 & 2.34 & 8659.6 & - & 2.34 & - & 1.03 & 2.34 & 398 & 2802 & 11869.21 \\
\hline \multicolumn{12}{|l|}{ HOTEL "D" } \\
\hline Housekeeper & 2.9 & 8.7 & 2153.77 & - & 4.35 & - & 0.64 & 17.4 & 62.1 & 433.32 & 2683.18 \\
\hline Reservation Chief & 2.9 & 8.7 & 2148 & - & 8.7 & - & 0.64 & 17.4 & 110 & 433.32 & 2729.66 \\
\hline F\&B Manager & 2.9 & 8.7 & 9081 & - & 23.8 & - & 0.64 & 17.4 & 143 & 433.32 & 9710.76 \\
\hline $\begin{array}{l}\text { Front Office } \\
\text { Manager }\end{array}$ & 2.9 & 8.7 & 10940 & - & 8.7 & - & 0.64 & 17.4 & 143 & 433.32 & 11554.66 \\
\hline \multicolumn{12}{|l|}{ HOTEL "E" } \\
\hline Housekeeper & 1.56 & 1.17 & 2019.5 & - & 1.53 & - & 0.78 & 2.34 & 286.62 & 14 & 2327.5 \\
\hline
\end{tabular}




\begin{tabular}{|c|c|c|c|c|c|c|c|c|c|c|c|}
\hline & 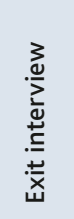 & 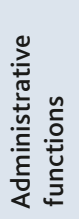 & 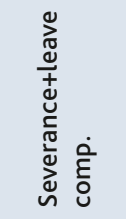 & $\begin{array}{l}\stackrel{0}{\dot{0}} \\
\text { है } \\
\text { है }\end{array}$ & 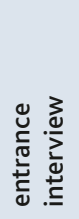 & 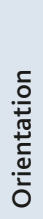 & 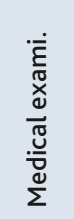 & 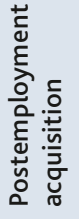 & 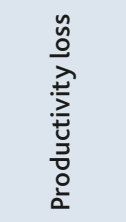 & . & 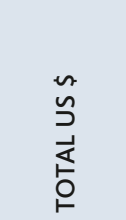 \\
\hline Reservation Chief & 1.56 & 1.17 & 1847.41 & - & 2.34 & - & 4.28 & 2.34 & 477.7 & 14 & 2350.8 \\
\hline F\&B Manager & 1.56 & 1.17 & 8964.6 & - & 9.34 & - & 4.28 & 1.17 & 323.24 & 14 & 9319.36 \\
\hline $\begin{array}{l}\text { Front Office } \\
\text { Manager }\end{array}$ & 1.56 & 1.17 & 11399.5 & - & 9.34 & - & 4.28 & 1.17 & 1051 & 14 & 12482.02 \\
\hline \multicolumn{12}{|l|}{ HOTEL "F" } \\
\hline Housekeeper & 0.74 & 5.94 & 1804.5 & - & 4.94 & - & 0.78 & 2.97 & 245.22 & 178.34 & 2243.43 \\
\hline Reservation Chief & 0.74 & 2.97 & 3557.3 & - & 9.34 & - & 2.26 & 2.97 & 3630.6 & 15.28 & 7221.46 \\
\hline F\&B Manager & 0.74 & 2.97 & 12767.3 & - & 17.67 & - & 0.78 & 2.97 & 17197.45 & 6.6 & 29996.48 \\
\hline $\begin{array}{l}\text { Front Office } \\
\text { Manager }\end{array}$ & 0.74 & 2.97 & 12634.81 & - & 11.78 & - & 0.78 & 1.48 & 10891.72 & 847.13 & 24391.41 \\
\hline
\end{tabular}

Table 4. Involuntary Turnover Costs For 2000

\begin{tabular}{|c|c|c|c|c|c|c|c|c|c|c|c|}
\hline & 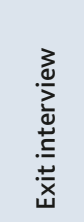 & 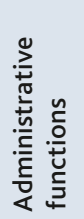 & 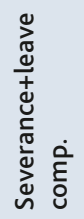 & 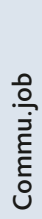 & 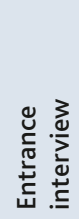 & 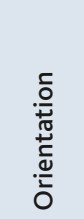 & 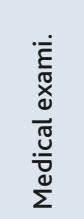 & 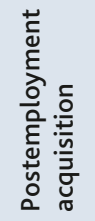 & 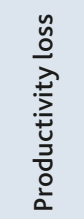 & 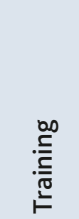 & $\begin{array}{l}n \\
\sim \\
د \\
\frac{1}{5} \\
0 \\
1\end{array}$ \\
\hline \multicolumn{12}{|l|}{ HOTEL "A" } \\
\hline Housekeeper & 2.21 & 0.81 & 978 & - & 4.42 & - & - & 0.19 & 63 & - & 1049 \\
\hline Reservation Chief & 2.22 & 1.38 & 1055 & - & 4.43 & - & - & 0.19 & 123 & - & 1186 \\
\hline F\&B Manager & 8.89 & 2.33 & 6293 & - & 11.11 & - & - & - & - & - & 6316 \\
\hline \multicolumn{12}{|l|}{ HOTEL "B" } \\
\hline Housekeeper & 1.12 & 1.12 & 746 & - & 2.18 & - & - & 0.083 & 52.73 & 24.11 & 827 \\
\hline Reservation Chief & 2.96 & 1.53 & 1205 & - & 2.96 & - & - & 0.084 & - & 211 & 1424 \\
\hline F\&B Manager & 11.38 & 1.67 & 4935 & - & 29.13 & - & - & - & 502 & - & 5479 \\
\hline \multicolumn{12}{|l|}{ HOTEL "C" } \\
\hline Housekeeper & 1.37 & 6.96 & 924 & - & 1.17 & - & 60 & 0.39 & - & 123 & 1117 \\
\hline Reservation Chief & 1.45 & 7.37 & 603 & - & 1.26 & - & 30 & 0.39 & - & 40 & 683 \\
\hline F\&B Manager & 1.67 & 5.02 & 3803 & - & 6.70 & - & 90.40 & - & - & - & 3906 \\
\hline \multicolumn{12}{|l|}{ HOTEL "D" } \\
\hline Housekeeper & 1.76 & 0.94 & 666 & - & 3 & 1.5 & 0.53 & 0.17 & 45.70 & 1.51 & 721 \\
\hline Reservation Chief & 1.76 & 1.17 & 591 & - & 3 & 1.5 & 0.53 & 0.17 & 20.09 & - & 619 \\
\hline F\&B Manager & 3.26 & 2.51 & 6122 & - & 5.27 & 5.02 & 0.53 & - & - & - & 6138 \\
\hline \multicolumn{12}{|l|}{ HOTEL "E" } \\
\hline Housekeeper & 0.86 & 2.15 & 2320 & - & 3.27 & 57.85 & - & 0.47 & 33.77 & 2953 & 5371 \\
\hline Reservation Chief & 14.20 & 3.41 & 1979 & - & 10.96 & - & - & 0.47 & 211 & 1476 & 3695 \\
\hline F\&B Manager & 28.39 & 9.37 & 6482 & - & 85.17 & - & - & - & 492 & 4429 & 11526 \\
\hline
\end{tabular}




\begin{tabular}{|c|c|c|c|c|c|c|c|c|c|c|c|}
\hline & 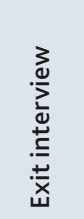 & 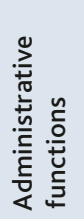 & 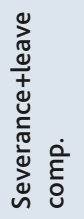 & 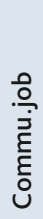 & 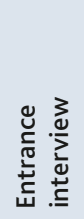 & 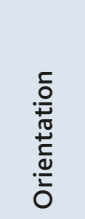 & 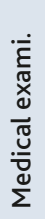 & 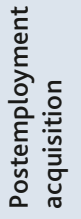 & 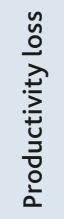 & 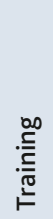 & 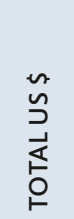 \\
\hline \multicolumn{12}{|l|}{ HOTEL "F" } \\
\hline Housekeeper & 4.32 & 0.32 & 3878 & - & 14.80 & 43.88 & - & 0.18 & 116 & - & 4058 \\
\hline Reservation Chief & 4.32 & 0.64 & 4450 & - & 16.90 & 45.54 & - & 0.50 & 314 & - & 4832 \\
\hline F\&B Manager & 15.07 & 0.81 & 8531 & - & 40.18 & 31.98 & - & - & - & - & 8619 \\
\hline
\end{tabular}

Table 5. Involuntary Turnover Costs For 2010

\begin{tabular}{|c|c|c|c|c|c|c|c|c|c|c|c|}
\hline & 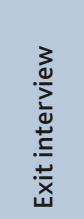 & 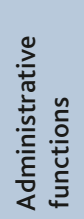 & 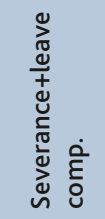 & 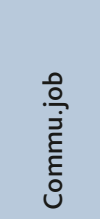 & 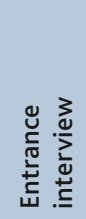 & 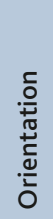 & 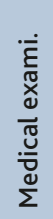 & 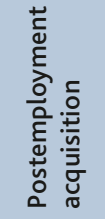 & 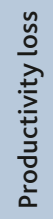 & 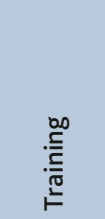 & $\begin{array}{l}n \\
\sim \\
د \\
\frac{1}{5} \\
0 \\
1\end{array}$ \\
\hline \multicolumn{12}{|l|}{ HOTEL "A" } \\
\hline Housekeeper & 5.10 & 25.13 & 4319.5 & 405.40 & 21.21 & - & - & 20.10 & - & 81.08 & 4877.52 \\
\hline Accounting Clerk & 5.10 & 25.13 & 2091 & 405.40 & 42.43 & - & - & 20.10 & - & 243.24 & 2832.4 \\
\hline Kitchen staff & 5.10 & 25.13 & 8350 & 405.40 & 21.21 & - & - & 16.53 & - & 81.08 & 8904.45 \\
\hline $\begin{array}{l}\text { Technical Service } \\
\text { Manager }\end{array}$ & 57.22 & 25.13 & 9635 & - & 57.22 & - & - & 20.10 & - & - & 9794.67 \\
\hline \multicolumn{12}{|l|}{ HOTEL "B" } \\
\hline Housekeeper & 4.05 & 7.29 & 3197 & 168.9 & 16.21 & - & - & 109.45 & - & 62.83 & 3565.73 \\
\hline Accounting Clerk & 4.05 & 7.29 & 1818 & 168.9 & 16.21 & - & - & 109.45 & - & 62.83 & 2186.73 \\
\hline Kitchen Staff & 4.05 & 7.29 & 6638.5 & 168.9 & 16.21 & - & - & 109.45 & - & 62.83 & 7007.23 \\
\hline $\begin{array}{l}\text { Technical Service } \\
\text { Manager }\end{array}$ & 23.10 & 7.29 & 10981.7 & - & 16.21 & - & - & 109.45 & - & - & 11137.75 \\
\hline \multicolumn{12}{|l|}{ HOTEL "C" } \\
\hline Housekeeper & 0.88 & 1.08 & 2339 & 337.85 & 2.83 & - & - & 48.64 & - & - & 2730.28 \\
\hline Accounting Clerk & 0.88 & 1.08 & 1331 & 337.8 & 2.83 & - & - & 48.64 & - & - & 1722.23 \\
\hline Kitchen Staff & 0.88 & 1.08 & 3348.6 & 337.8 & 2.83 & - & - & 48.64 & - & - & 3739.83 \\
\hline $\begin{array}{l}\text { Technical Service } \\
\text { Manager }\end{array}$ & 0.88 & 1.08 & 8466 & - & 11.35 & - & - & 48.64 & - & - & 8527.95 \\
\hline \multicolumn{12}{|l|}{ HOTEL "D" } \\
\hline Housekeeper & 2.53 & 5.47 & 4494 & 405.4 & 6.28 & - & - & 20.27 & - & 20.27 & 4954.22 \\
\hline Accounting Clerk & 2.53 & 5.47 & 2191 & 405.4 & 6.28 & - & - & 20.27 & - & 20.27 & 2651.22 \\
\hline Kitchen Staff & 2.53 & 5.47 & 8445.9 & 405.4 & 6.28 & - & - & 20.27 & - & 20.27 & 8906.12 \\
\hline $\begin{array}{l}\text { Technical Service } \\
\text { Manager }\end{array}$ & 27.56 & 5.47 & 11495.9 & - & 28.78 & - & - & 20.27 & - & - & 11577.98 \\
\hline \multicolumn{12}{|l|}{ HOTEL "E" } \\
\hline Housekeeper & 0.62 & 1.88 & 4075.6 & - & 3.64 & - & - & 3.68 & - & - & 4085.42 \\
\hline Accounting Clerk & 0.62 & 1.88 & 1643.9 & - & 3.64 & - & - & 3.68 & - & - & 1653.72 \\
\hline
\end{tabular}




\begin{tabular}{|c|c|c|c|c|c|c|c|c|c|c|c|}
\hline & 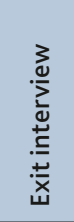 & 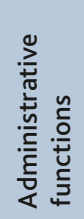 & 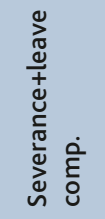 & 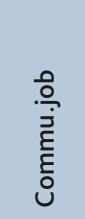 & 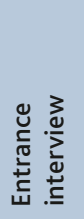 & 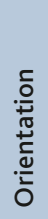 & 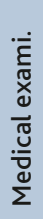 & 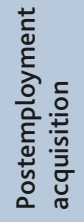 & 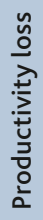 & 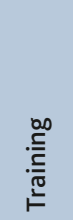 & 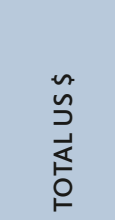 \\
\hline Kitchen Staff & 0.62 & 1.88 & 6750.6 & - & 3.64 & - & - & 3.68 & - & - & 6760.42 \\
\hline $\begin{array}{l}\text { Technical Service } \\
\text { Manager }\end{array}$ & 3.77 & 1.88 & 9910.8 & - & 3.64 & - & - & 3.68 & - & - & 9923.77 \\
\hline \multicolumn{12}{|l|}{ HOTEL "F" } \\
\hline Housekeeper & 2.63 & 6.48 & 2556.7 & 67.56 & 4.96 & - & - & 9.32 & - & - & 2647.65 \\
\hline Accounting Clerk & 2.63 & 6.48 & 2008 & 67.56 & 4.96 & - & - & 9.32 & - & - & 2098.95 \\
\hline Kitchen Staff & 2.63 & 6.48 & 3675 & 67.56 & 4.96 & - & - & 9.32 & - & - & 3765.95 \\
\hline $\begin{array}{l}\text { Technical Service } \\
\text { Manager }\end{array}$ & 10.13 & 6.48 & 10439 & 67.56 & 4.96 & - & - & 9.32 & - & - & 10537.45 \\
\hline \multicolumn{12}{|l|}{ HOTEL "G" } \\
\hline Housekeeper & 4.05 & 10.94 & 3146.6 & - & 8.37 & - & - & 14.59 & - & 6.95 & 3191.5 \\
\hline Accounting Clerk & 4.05 & 10.94 & 1455 & - & 8.37 & - & - & 14.59 & - & 6.95 & 1499.9 \\
\hline Kitchen Staff & 4.05 & 10.94 & 2567.5 & - & 8.37 & - & - & 14.59 & - & 6.95 & 2612.4 \\
\hline $\begin{array}{l}\text { Technical Service } \\
\text { Manager }\end{array}$ & 4.05 & 10.94 & 11847.9 & - & 8.37 & - & - & 14.59 & - & - & 11885.85 \\
\hline
\end{tabular}

